\title{
AN HISTORICAL ANALYSIS OF THE PRINCIPLE OF DOUBLE EFFECT
}

\author{
JOSEPH T. MANGAN, S.J. \\ St. Mary of the Lake, Mundelein
}

The principle of the double effect is one of the most practical in the study of moral theology. As a principle it is important not so much in purely theoretical matters as in the application of theory to practical cases. It is especially necessary in the subject matter of scandal, material cooperation, illicit pleasure and of injury done to oneself or to another. Although it is a fundamental principle, it is far from a simple one; and moralists readily admit its complexity. Moreover, it is not an inflexible rule or mathematical formula, but rather an efficient guide to prudent moral judgment in solving the more difficult cases. It is a subtle principle, and for this reason it is liable to misuse on the part of the untrained mind. Even moralists need to proceed cautiously in its practical application. Frequently, in making applications to identical cases, moralists arrive at opposite conclusions. Nevertheless, the principle is perfectly valid and justifiable by reason and Catholic tradition. ${ }^{1}$ Reasonably enough this principle has not always been as well understood and put in practice by scholars and others as it is today and as its worth merits. And the historical development of this principle presents an interesting study involving some controversy.

In its application, the principle of the double effect may have been understood implicitly many centuries before it was actually formulated. Even as far back as the events of the Old Testament, we find examples of moral actions justifiable under this principle. That the persons who performed these actions were implicitly using this principle we are not certain; for there are other explanations to justify their ac-

1 Thomas Tamburini, S.J., Theologia Moralis (Venetiis, 1755), t. 1, 1. 5, c., *4, n. 17; Hermanus Busembaum, S.J., Medulla Theologiae Moralis (Tornaci, 1848), t. 1, 1. 2, tr. 3, c. 2, art. 3; St. Alphonsus de Ligorio, Theologia Moralis (ed. Gaudé) (Romae, 1905-1912), t. 1, 1. 2, tr. 3, c. 2, dub. 5, art. 3, n. 63; Augustinus Lehmkuhl, S.J., Theologia Moralis (Friburgi Brisgoviae, 1887 and 1914), v. 1, "Theol. Mor. Spec.," p. 1, 1. 2, div. 1, c. 3, n. 806; T. Lincoln Bouscaren, S.J., Ethics of Ectopic Operations (Bruce Publishing Co.: Milwaukee, Wis., 1944), pp. 37, 38; John C. Ford, S.J., "The Morality of Obliteration Bombing," Theological Studies, V (Sept., 1944), 289; and many others. 
tions, of which Holy Scripture seems to approve. There is, for instance, the story of Eleazar in the sixth chapter of the First Book of the Machabees. When the Jews were at war with a hostile king, one of the Jews, Eleazar, the son of Saura, performed a very brave deed. He noticed that one of the elephants in the ranks of the enemy was harnessed with the king's harness. Moreover, this elephant was taller than the others and it seemed to Eleazar that the king was on it. Therefore, Eleazar decided to risk the danger of fighting alone through the ranks around the king in order to destroy him. Fighting furiously against the enemy and killing them right and left, he finally reached the elephant. His only hope of bringing down the beast lay on his going between the massive legs and cutting through the tough hide with deadly sword thrusts. This he did, foreseeing that the elephant's fall would kill him too. This brave deed is one of the scriptural deeds justifiable under the principle of the double effect.

However, before the time of St. Thomas Aquinas there is no indication of a definitely formulated principle of the double effect. Beginning with St. Thomas, the development of this important principle kept pace, more or less, with the growth of the study of moral theology itself. But St. Thomas and the other early moral theologians gave no special treatment to the principle. In their writings it receives mention only in connection with some particular application of moral theology. For example, St. Thomas and Cajetan mention it mainly in the discussion of defense against unjust aggression; others, who do not use it to justify killing in self-defense, find place for it in the problem of the morality of killing the innocent, of mutilating or killing one's self, of material cooperation in another's sin, or of illicit venereal pleasure. Then, as moral theology gradually developed, the principle took a more and more prominent place, until today in all the manuals of moral theology we find a special section devoted to it. This section has its proper place among the explanations of the general principles, usually under the general heading of the principles of imputability. After once giving their explanations of this principle of the double effect, the authors later on in their treatises make frequent reference to it in their solutions of the more difficult cases especially of scandal, material cooperation, justifiable killing and the rest.

All moralists agree substantially on the statement of the principle, 
although some word it a little differently from others. Some authors express four conditions, others taking one or another condition for granted express only three or two conditions. ${ }^{2}$ For the further purposes of this article we shall consider the principle with four conditions. Formulated, therefore, in its full modern dress, it may be expressed as follows: A person may licitly perform an action that he foresees will produce a good and a bad effect provided that four conditions are verified at one and the same time: 1) that the action in itself from its very object be good or at least indifferent; 2) that the good effect and not the evil effect be intended; 3) that the good effect be not produced by means of the evil effect; 4 ) that there be a proportionately grave reason for permitting the evil effect.

In this article it is our intention to discuss in detail only the historical beginnings of the principle of the double effect from the time of its initial formulation until it was accepted by moralists generally, and its historical development to modern times. Therefore, an explicit critical analysis of the principle is outside the scope of the present study, as is also a presentation of the principle in the modern authors generally.

\section{ST. THOMAS}

We have stated that before the time of St. Thomas Aquinas there is no indication of a definite formulation of the principle of the double effect. Now, we must admit that it is not entirely clear that St. Thomas himself enunciates this principle; according to some interpreters he does, according to others he does not. The text giving rise to these contrary interpretations is the famous explanation of the lawfulness of killing another in self-defense in the Summa Theologica, II-II, q. 64, a. 7 c. In answering the question, whether it is law-

${ }^{2}$ Joannes P. Gury, S.J., Compendium Theologiae Moralis (Lugduni, 1850; Ratisbonae, 1874), t. 1, "De actibus humanis," c. 2, n. 6-9; Gulielmus J. Walsh, Tractatus de actibus humanis (Dublinii, 1880), c. 2, art, 2, n. 155; Lehmkuhl, op. cit., v. 1, tr. 1, c. 2, n. 72; Ad. Tanquerey, Synopsis Theologiae Moralis et Pastoralis (Romae, 1906), t. 2, tr. "De actibus humanis," c. 2, n. 175; Joannes N. Ferreres, S.J., Compendium Theologice Moralis (Barcinone, 1921), t. 1, tr. 1, c. 2, n. 60; Joseph Ubach, S.J., Compendium Theologiae Moralis (Friburgi Brisgoviae, 1926), v. 1, tr. 1, art. 1, n. 9; Joseph Creusen, S. J., Quelques problèmes de morale professionelle (Paris, 1935), p. 27; Arthurus Vermeersch, S.J., Theologiae Moralis (Romae, 1933, sq.), t. 1, n. 117, 118; Seraphinus A. Loiano, O.M.Cap., Institutiones Theologiae Moralis (Taurini, 1934, sq.) v. 1, n. 28, VI; and many others. 
ful to kill another in self-defense, St. Thomas says in the body of the article:

I answer that there is nothing to prevent one act from having two effects, of which only one is intended by the agent and the other is outside of his intention. Now, moral actions receive their character according to what is intended, and not from what is outside of the intention, since that is "per accidens," as has been stated (q. 43, a. 3; and I-II, q. 1, a. 3, ad 3m). Therefore, from the act of a person defending himself a twofold effect can follow: one, the saving of one's own life; the other, the killing of the aggressor. Such an act, therefore, insofar as the conservation of one's own life is intended, is not illicit, since it is natural to every being to preserve its life as far as possible. Nevertheless, an act which proceeds from a good intention may be rendered illicit, if it is not proportioned to the end intended. Hence, if one uses greater violence than is necessary in defending his own life, his act will be illicit. But, if with due moderation he repels the violence offered him, his defense of himself will be licit; for according to law one may repel violence with violence, if he observes the moderation of a blameless selfdefense. And it is not necessary for salvation that a man when attacked should forego such an act of moderate defense in order to avoid slaying the aggressor; for a man is under stricter obligation to protect his own life than another's.

Yet, since it is unlawful to kill a man except by public authority for the common good, as explained above (a. 3, of this question), it is, therefore, wrong for a man to intend to kill another as a means to defend himself, except in the case of one invested with public authority, who, in intending to kill another in defense of his own life, refers the act to the common good, as for example when a soldier fights against the enemy or an officer of the law fights against robbers. However, even these would commit sin, if they acted on motives of private spite.

The crux of the difficulty in interpreting this text lies in the proper understanding of what St. Thomas meant by his terms intendere and non intendere, ex intentione and praeter intentionem. If, according to the mind of St. Thomas, "intendere," when spoken of the will, refers only to the ultimate end of an action, then St. Thomas in this text does not enunciate the principle of the double effect as we understand it today. For, in this hypothesis, St. Thomas would be asserting that the defender cannot lawfully intend the death of the aggressor as the ultimate end of his action, but he can lawfully will the death as a 
means to the end of his own defense. However, if the principle of the double effect were invoked by St. Thomas, the author of the action could not lawfully will the evil effect as a means to the good effect; for this is contrary to the third condition of the principle. On the other hand, if St. Thomas, as we contend uses the word intendere to refer also to the means to the ultimate end, then in this text he does clearly enunciate the principle of the double effect. For, in this hypothesis, St. Thomas would be asserting that the defender cannot lawfully will the death of the aggressor either as a means to the ultimate end of the action or as the ultimate end itself. The defender can lawfully intend only his own defense; if the death of the unjust agressor follows, it is not intended.

The older moralists who maintain that St. Thomas did not enunciate the principle of the double effect in this passage merely assert their own opinion of what St. Thomas meant. Thus Lessius maintains that St. Thomas held that it is lawful in an act of self-defense to intend everything, even the death of another, that is judged necessary for the defense of one's life and bodily members. ${ }^{3}$ Dominicus de Soto and Gabriel Vasquez give a similar interpretation." Hence, if their interpretation is the true one, St. Thomas did not apply the principle of the double effect.

Although this interpretation was more or less abandoned for many years, in recent times there has appeared a scholarly and most extensive discussion in its defense. In his Gregorian University dissertation, published in 1937, Vicente M. Alonso, S.J., concludes that St. Thomas held merely that the killing of an unjust aggressor may be willed as a means but not as an end in itself. ${ }^{5}$ Even his scholarly study, however, leaves room for serious doubt with regard to his conclusions about the true meaning of St. Thomas.

Alonso studies the explanation of St. Thomas in the light of the opinion of St. Thomas' predecessors and contemporaries, and in the light of the meaning given before his time and in his other works to the terms St. Thomas uses; he also calls attention to the position of

'Leonardus Lessius, S.J., De justitia et jure (Mediolani, 1613), 1. 2, c. 9, dub. 8, n. 53.

' Dominicus de Soto, O.P., De justitia et jure, 1. 5, q. 1, art. 8; Gabriel Vasquez, S.J., Opuscula moralia (Lugduni, 1620), "De restitutione," c. 2, par. 1, dub. IV.

- Vincentius M. Alonso, S.J., El principio del doble efecto en los comentadores de Santo Tomas de Aquino (Romae, 1937). 
the explanation in the internal plan of question 64 in the Secunda Secundae. But he does not credit St. Thomas with any special development of thought in the question under discussion. He believes that the cause of confusion in the interpretation of this question is that the authors do not give sufficient recognition to St. Thomas' historical environment. In consequence St. Thomas' terms have been given a meaning which they did not have at the time he wrote. ${ }^{6}$ He summarily concludes that the principle according to which St. Thomas considers that one act can have two effects, one of which is ex intentione, and the other only praeter intentionem, has nothing at all to do with the principle of the double effect as it is understood today. For, insofar as these effects are considered materially (in the physical order), the death of the aggressor is a means or a conditio sine qua non for the preservation of one's life. By no means is the death considered as an effect that comes equally immediately from the same cause as the defense of one's life. And in the intentional order, the term praeter intentionem by no means prohibits the effect, death, from being deliberate and from being chosen directly by the will as a lawful means towards an equally lawful end. ${ }^{7}$

Although Alonso's presentation of arguments and conclusions is quite formidable, it does not eliminate the reasonableness of the

- Alonso, op. cit., part 4, at the end.

${ }^{7}$ Alonso, op. cit., part 4, at the very end: "Con esto creemos poder concluir este capitulo afirmando salvo meliore iudicio, que en el articulo septimo de la cuestion 64 de la Secunda Secundae, no se trata de uno caso de doble efecto en la signification que modernamente damos a estos terminos; y que el principio que Sto. Tomas pone como fundamento de la cuestion, de que un acto puede tener dos efectos, de los cuales uno sea ex intentione y el otro solo praeter intentionem, nada tiene que ver, con el principio nuestro del doble efecto, ni en cuanto a la consideracion de los efectos fisicos materialmente considerados, por tratarse en el caso de la muerte del agresor de un medio o condicion 'sine qua non' para la conservacion de la vida, y de ninguna manera de dos efectos que 'aeque immediate' provienen de una causa; ni en el orden intencional el praeter intentionem de ninguna manera excluye el que tal efecto sea voluntario y como tal elegido por la voluntad como medio licito para la consecucion de un fin igualmente licito, $y$ al cual tiene derecho, y no solamente un efecto simplemente permitido, si bien no pretendido o (intentus) como fin, ni querida simplemente, sino en cuanto se refiere y es necesaria para defenderse, que es lo unico que constituye el fin hacia el cual tiende la voluntad. Se trata pues de un acto directamente voluntario. Creemos que la causa de tanta confusion, acera de un punto que ahora nos parece tan claro ha sido el haber interpretado al Sto. Doctor fuera del cuadro historico e ideologico en que escribio y haber dado a sus terminos una significacion en la que nunca penso y que esta en abierta contradiccion con la mentalidad de la epoca y con la admirable unidad de pensamiento en que el Doctor Angelico concibio su Suma Teologica." 
opposite, more or less traditional interpretation of St. Thomas. For Alonso seems to have overlooked a few pertinent considerations in his interpretation of the various parts of the Summa Theologica of St. Thomas.

First of all, he neglects almost entirely the distinction St. Thomas makes between the two kinds of ends that an individual may intendone the ultimate end of an action and the other an intermediary end, which is a means to the ultimate end. And St. Thomas explains that both of these ends are intended. ${ }^{8}$ Consequently, in the Summa Theologica, where Alonso prefers to interpret "intention of an end," to mean "intention of an ultimate end," we can sometimes legitimately interpret St. Thomas' meaning to refer also to an intermediary end, which is a means to the ultimate end. Or we can follow the terminology of the responses given in another part of the Summa Theologica and in De malo. ${ }^{9}$ Then we would divide the various ends into proximate and remote, of which the proximate is ordained to the remote. Therefore, the intention, although again referring to an end, may refer to the proximate as well as to the remote end. We admit that this may seem to indicate a development in the mind of St. Thomas, if we compare these passages with a passage in the Contra Gentes, quoted by Alonso in favor of his interpretation. For, in the Contra Gentes, 1. 3, c. 6, St. Thomas explicitly mentions that "intentio" refers to the ultimate end.10

Or, together with St. Thomas, we may reason this way: A moral act is divided into object, circumstances, and end. ${ }^{11}$ But the object, even though it is not the matter about which the act is terminated, of its very nature is an end which the agent intends. ${ }^{12}$ Hence, if a circumstance becomes a part of the object, it participates in the nature of the object, and of its nature is an end which the agent intends. ${ }^{13}$ Therefore, in St. Thomas' mind also, when he wrote the Summa

Sum. Theol., I-II, q. 12, a. 2c; q. 1, a. 3, ad 3; De malo, q. 2, a. 6, ad 9.

Sum. Theol., I-II, q. 1, a. 3, ad 3; De malo, q. 2, a. 6, ad 9.

${ }^{10}$ Contra Gentes, 1. 3, c. 6: "Intentio enim est ultimi finis."

${ }^{11}$ Sum. Theol., I-II, q. 18, a. 1, 2, 3, 4, 5, 10.

12 Sum. Theol., I-II, q. 73, a. 3, ad 1: "Objectum, etsi sit materia circa quam terminatur actus, habet tamen rationem finis, secundum quod intentio agentis fertur in ipsum." Vd. also II-I, q. 72, a. 3, ad 2.

${ }^{13}$ Sum. Theol., I-II, q. 18, a. 5, ad 4; q. 18, a. 10c, et ad 1, 2; De malo, q. 2, a. 6, ad 1, 2; a. $7 \mathrm{c}$, et ad 8 . 
Theologica, the agent always intends the object of the moral action and not only the ultimate end. And the object of the moral action is almost always, if not always, a means to the ultimate end of the action. For it is what is primarily intended, in order to bring about the ultimate end intended by the agent.

Now, it is our contention that Alonso's arguments do not eliminate the reasonableness of applying the preceding distinctions and explanations to the body of article seven in II-II, q. 64. Accordingly, by saying that "it is wrong for a man to intend to kill another as a means to defend himself," St. Thomas can reasonably be interpreted to mean that it is wrong for a man to will the death of another as part of the object of his moral act, or as an intermediary end to the ultimate end of his own defense, or as a proximate end directed to the remote end of his own defense. ${ }^{14}$ Such an interpretation eliminates Alonso's conclusion that St. Thomas was not treating of the principle of the double effect, at least in its main points, as we understand it today. For, if the defender willed the death of the aggressor as part of the object of his moral act, he would intend the death as a means to his own defense. If he willed the death as an intermediary end, he would intend the death as a means to the ultimate end. If he willed the death as a proximate end, he would intend the death as a means to the remote end. Consequently, St. Thomas' mind, according to our interpretation, would be that the defender cannot will or intend the death of the aggressor as an end in itself and for itself, or as a means to the end of his own defense.

Furthermore, Alonso's interpretation encounters another difficulty to which he himself neglected even to attempt an answer. According to his interpretation, when St. Thomas says that the public authority may intend the death of a criminal, he must mean that the public authority may intend the death of a criminal as an ultimate end, and not only as a means to the common good. Yet, what St. Thomas says in article two, three, and seven of q. 64 of the Secunda Secundae seems contrary to this interpretation. There St. Thomas says only that the public authority can kill a criminal "to preserve the common good," "insofar as the killing is ordained to the preservation of the

${ }^{14}$ Sum. Theol., II-II, q. 64, a. 7c: "Illicitum est quod homo intendat occidere hominem, ut se ipsum defendat...." 
common good," "for the common good," and finally, "if the killer refers the act to the common good." And in the seventh article the word "to intend" is used explicitly. Therefore, according to St. Thomas' own use of the word in article seven, "to intend" also signifies to intend as a means to an end; for he limits the lawfulness of killing by public authority to killing as a means, or as an intermediary end, or as a proximate end to that of the common good.

Our final conclusion to this discussion of Alonso's opinion is that not only is it quite reasonable but it is more reasonable to interpret II-II, q. 64, a. 7 as an enunciation of the principle of the double effect as we understand it today, and as an application of that principle to the lawfulness of killing in self-defense. ${ }^{16}$

We shall now undertake an explanation of this passage according to the principle of the double effect. First, St. Thomas gives the general statement of the possibility that "there is nothing to prevent an act from having two effects, of which only one is intended by the agent and the other is outside the intention." To prove that such an act can be lawful, he goes on to explain that even though one effect is bad, still, if that effect is not intended, the act could be licit, because "moral actions receive their character according to what is intended and not from what is outside the intention, since that is per accidens." But from the very fact that two effects, one good and one bad, follow from the act in which only the good effect is intended, we cannot conclude that the act is lawful. For, St. Thomas adds, "an act that proceeds from a good intention may be rendered illicit, if it is not proportioned to the end intended." Therefore, it is necessary to analyse the act and its effects to determine in a particular case whether or not such an act is lawful. And this St. Thomas does in the case of a man defending himself against an unjust aggressor.

${ }^{15}$ Some other authors who give the same interpretation: Thomas Card. Cajetan, O.P., Commentarium in Summa S. Thomae in Sti. Thomae Aquinatis opera omnia (Romae, 1882 sq.), II-II, q. 64, a. 7; Francisco de Vitoria, O.P., Comentarios a la Secunda Secundae de Santo Tomas (Edition praeparada por el R. P. Vicente Beltram de Heredia, O.P.) (Salamanca, 1934), II-II, q. 64, a. 7; Johannes Card. De Lugo, S.J., De justitia et jure, disp. 10, sect. 6, n. 148; Joannes a S. Thoma, O.P., Cursus Theologicus, (Parisiis, 1886), t. 7, q. 64, disp. 11, a. 4, n. 11; Gregorius de Valentia; S.J., Commentariorum Theologicorum (Venetiis, 1608), t. 3, disp. 5, q. 8, punct. 4, n. 1075 B; Salmanticenses Morales, Cursus Theologiae Moralis (Venetiis, 1734), t. 6, tr. 26, c. 7, punct. 3, n. 45. 
In making his application to the case of self-defense, Thomas finds that the act of self-defense can have two effects, one good and one bad. For, he says: "From the act of a person defending himself a twofold effect can follow: one, the saving of one's own life; the other, the killing of the aggressor." He finds, further, that the four conditions of the principle of the double effect can be verified, so that an act of self-defense with the bad effect included can be lawful.

The first condition, that the action must be objectively good or indifferent, he applies by observing that "such an act, insofar as the conservation of one's own life is intended, is not illicit, since it is natural to every being to preserve its life as far as possible." The second condition, that the good effect and not the evil effect must be intended as the ultimate end of the action, is implicit throughout the whole passage. There is no doubt whatever that this condition is present, because, according to St. Thomas and all moralists, if the ultimate end of the action is bad, the action is illicit. The third condition, that the good effect must not be produced by means of the evil effect, is the condition which Alonso denies to be present. Hence, our answer to Alonso substantiates our claim that when St. Thomas wrote that "it is therefore wrong for a man to intend to kill another as a means to defend himself," he was applying this third condition. If this interpretation is the true one, the second condition follows $a$ fortiori; for, if the evil may not be intended as a means to an end, it certainly may not be intended as the ultimate end itself. ${ }^{16}$ The fourth condition, that there must be a proportionately grave reason for permitting the evil effect, St. Thomas explains at length. "Nevertheless," he writes, "an act which proceeds from a good intention may be rendered illicit, if it is not proportioned to the end intended. Hence, if one uses greater violence than is necessary in defending his own life, his act will be illicit. But, if with due moderation he repels the violence offered him, his defense of himself will be licit; for, according to law, one may repel violence with violence, if he observes the moderation of a blameless self-defense. And it is not necessary for salvation that a man when attacked should forego such an act of moderate defense, in order to avoid slaying the aggressor; for a man is under stricter obligation to protect his own life than another's."

${ }^{16}$ Bouscaren, op. cit., p. 33. 
The passage just explained at length seems to be the only one in which St. Thomas enunciates and explicitly applies the principle of the double effect. Consequently, we can safely say that the only case to which St. Thomas may be said with any degree of certainty to have applied the principle is to the case of self-defense against an unjust aggressor. However, there are indications in other sections of the Summa Theologica that he may have had this principle in view when he wrote.

When he treats the questions, "Whether spiritually good acts are to be omitted because of scandal," and "Whether temporal things are to be omitted because of scandal," he seems to be applying the principle of the double effect without making explicit mention of it. ${ }^{17}$ $\mathrm{He}$ admits that passive scandal, if it is pharisaical or equivalent to pharisaical, may be permitted when the intention is to perform spiritually good acts. ${ }^{18}$ And in the next article, he admits that one may permit passive scandal rather than forego temporal goods. ${ }^{19}$ Here we have examples of actions which have two effects, one of which is good and the other bad, spiritual or temporal good and passive scandal. The actions in themselves are objectively good or indifferent. The good effect is intended as the ultimate end of the action and the scandal is merely permitted. The bad effect is not intended as the ultimate end or as a means to the good effect. There is a proportionate reason for permitting the evil effect. However, in deciding these cases, St. Thomas makes no reference whatever to the principle of the double effect. He just gives his answer with the reason why there is a proportionate reason for permitting the evil effect..$^{20}$

But, even though St. Thomas applied the principle explicitly only to one case, he at least enunciated the principle, according to our interpretation; and he seems to have been the first to do so. Further-

${ }^{17}$ Sum. Theol., II-II, q. 43, a. 7, 8. $\quad{ }^{18}$ Sum. Theol., II-II, q. 43, a. 7c.

${ }^{19}$ Sum. Theol., II-II, q. 43, a. 8c; vd. also II-II, q. 78, a. 4, and ad 1, 2, 3.

${ }^{20}$ Sum. Theol., II-II, q. 67, a. 2c; q. 169, a. 2, ad 4; q. 169, a. 4c. Vd. also De malo, q. 13, a. 4, ad 19: "Ad decimum nonum dicendum, quod pro nullo incommodo corporali vitando debet homo consentire in peccatum alterius; sed tamen pro aliquo incommodo vitando potest homo licite uti malitia alterius, vel materiam ei non subtrahere, sed praebere: sicut si latro aliquem jugulare vellet, et ad vitandum mortis periculum aliquis latroni thesaurum suum diripiendum detegeret, non peccaret, examplo illorum decem virorum, qui dixerunt ad Ismael: 'Noli occidere nos, quia habemus thesaurum in agro,' ut habetur Hierem. 41, 8."? 
more, even if, as a matter of cold objective truth and according to Alonso's interpretation, St. Thomas did not teach the principle of the double effect as we understand it today, he still gave the initial impetus to its explanation and application in the authors who follow him even to the present. Many of the moralists who follow St. Thomas, in their explanation of the principle of the double effect refer to the principle enunciated by St. Thomas in II-II, q. 64, a. 7, and they give no other earlier author as a reference, except to quote one or other example used by these earlier authors. For these reasons, therefore, we claim this article of the Summa Theologica as the historical beginning of the principle of the double effect as a formulated principle.

\section{THE SIXTEENTH AND SEVENTEENTH CENTURIES}

For about two hundred years after St. Thomas nothing seems to have been written to further the understanding of the principle of the double effect. Then at the beginning of the sixteenth century, in his commentary on the Summa Theologica, Cardinal Cajetan, Thomas de Vio, O.P., made a definite contribution to the historical advance of the principle. There is no doubt in the wording of Cajetan, that he interprets II-II, q. 64, a. 7 in terms of the principle of the double effect as we understand it today. Hence, even if some persist in maintaining that St. Thomas did not refer to this principle in his explanation of the lawfulness of self-defense against an unjust aggressor, they must admit that at least Cajetan thought he did, and that Cajetan himself applied the principle to killing in self-defense.

The first thing Cajetan does for us is to clarify the meaning of St. Thomas. He explains that both the end, meaning the ultimate end, and the means come under one's intention. And he stresses that the death in the case in question is an effect that flows necessarily from the defense, but is not intended as a means to the ultimate end or as the end itself. ${ }^{21} \mathrm{He}$ adds a little more to our understanding of

${ }^{21}$ Cajetan, op. cit., II-II, q. 64, a. 7: "Dupliciter potest referri occisio alterius ad conservationem vitae propriae: primo, ut medium ad finem; secundo, ut consequens ex necessitate finis. Et ut in littera dicitur, multum interest altero modo se habere. Nam et finis et medium ad finem cadunt sub intentione: ut patet in medico, qui intendit sanitatem per potionem vel diaetam. Id autem quod consequitur ex necessitate finis non cadit sub intentione, sed praeter intentionem existens emergit: ut patet de debilitatione aegroti quae 
the last condition of the principle when in the same article he goes into detail to show that there is due proportion between the defense of one's own life and death of the aggressor, and between the defense of one's own goods and the death of the aggressor. He does this in answering the doubt that due proportion does exist. ${ }^{22}$

The distinction that Cajetan makes is between the greater love that one must have for the eternal welfare of the aggressor than for one's own temporal life, and the more special responsibility one has to care for one's own body than for that of one's neighbor. He makes the same distinction with regards to one's temporal goods. For he maintains that, although one must have greater love for the eternal welfare of the aggressor than for one's own temporal goods, still one has more special responsibility to take care of one's own temporal goods. Hence, if the aggressor is stealing those goods and there is no way of preserving or recovering them except by a defense which will result in the death of the aggressor, such a defense is lawful. ${ }^{23}$ That this interpretation, especially in the matter of one's temporal goods, needs further explanation and more distinctions, is clear in the light of the subsequent progress of moral theology.

In this same place, Cajetan further asserts that due proportion exists also between the killing of the aggressor and the defense of one's virtue; and that one thus defending his virtue does so with more reason than one defending his external goods. Moreover, Cajetan seems to be the first to apply the principle of the double effect explicitly to the killing of innocent people. For he maintains that to intend to kill an innocent person as an end in itself or as a means to an end is contrary to all rights. But to kill an innocent person per accidens, by doing something that is lawful and necessary, as one does who is administering a public office, is not contrary to natural law, divine or written law. Cajetan makes this assertion when he is explaining how

sequitur ex medicina sanante. Et juxta duos hos modos diversimode occidere potest licite persona publica et privata. Nam persona publica ut miles, ordinat occisionem hostis ut medium ad finem subordinatum bono communi, ut in littera dicitur: persona autem privato non intendit occidere ut seipsum salvet, sed intendit salvare seipsum, non destiturus a sui defensione etiam si alterius mortem ex sua defensione oporteat sequi. Et sic iste non occidit nisi per accidens: ille autem per se occidit. Et propterea ad illud requiritur publica auctoritas, ad hoc non."

2ajetan, op. cit., II-II, q. 64, a. 7. $\quad$ Cajetan, op. cit., II-II, q. 64, a. 7. 
a judge can condemn to death a man who from private knowledge he knows to be innocent, although the evidence in the court indicates the man as guilty. ${ }^{24}$

The development of the principle of the double effect was begun by Cajetan at the beginning of the sixteenth century; as the century wears on and turns into the seventeenth, the principle is applied to more and more specific cases and one or other author gives it more explicit treatment as a principle. By the beginning of the seventeenth century, the principle of the double effect is accepted in its application to particular cases by moralists generally. For, although many moralists of that period deny that the principle is needed to justify killing in self-defense, they still implicitly maintain the principle and apply it in other cases. They reject the necessity of the principle to justify killing in self-defense, because they maintain that it is lawful to intend to kill an unjust aggressor when that is necessary to preserve one's life. ${ }^{25}$

The examples to which the principle was quite commonly applied by the beginning of the seventeenth century are the following: indirect killing of the innocent, especially in time of war; ${ }^{26}$ exposing oneself to mortal danger for a good cause ${ }^{27}$ performing some act which

थ Cajetan, op. cit., II-II, q. 67, a. 2, n. V; vd. also I-II, q. 20, a. 5; and II-II, q. 147' a. 4 , n. VII.

${ }^{25}$ Ludovicus Molina, S.J., De justitia et jure (Moguntiae, 1659), t. 4, tr. 3, disp. 11; Soto, op. cit., 1. 5, q. 1, a. 8; Lessius, op. cit., 1. 2, c. 9, dub. 8, n. 53; Vasquez, op. cit., "De restitutione," c. 3 , par. 1 , dub. VI.

${ }^{26}$ Vitoria, op. cit., II-II, q. 64, a. 6, n. 6; Molina, op. cit., t. 1, disp. 119; Toletus, Franciscus, S.J., Enarratio in Summam Theologiae S. Thomae Aquinatis (ed. Joseph Paria, S.J.) (Romae, 1869), t. 2, q. 34, a. 1, and q. 64, a. 6; Franciscus Suarez, S.J., Opera Omnia (ed. Carolus Berton) (Parisiis, 1856 sq.), t. 12, tr. 3, disp. 13, sect. 7, n. 1519; Lessius, op. cit., 1. 2, c. 9, dub. 7, n. 36 ff.; and n. 57-59; 1. 2, c. 9, dub. 10, n. 62; Joannes Azorio, S.J., Institutionum Moralium (Brixiae, 1617), t. 3, 1. 2, c. 7, n. 135, A, B; Paul Laymann, S.J., Theologia Moralis (Venetiis, 1714), 1. 2, tr. 3, c. 12, n. 11, 12; Bonacina Martinus, Opera Omnia Sacrae Theologiae (Venetiis, 1698), 1. 2, "De restitution," disp. 2, q. ult., sect. 1, punct. 7, n. 13; John Wiggers, De jure et justitia (Lovanii, 1651), tr. 2, c. 2, dub. 8, n. 38; Aegidius, De Coninck, S.J., De sacramentis et censuris (Antwerpiae, 1624), t. 2, disp. 34, dub. 4, n. 27; t. 2, disp. 13, dub. 13, n. 109; t. 1, q. 66, dub. 1, n. 71-75; Valentia, op. cit., t. 3 , disp. 5, q. 8, punct. 2, n. 1063, 1064; disp. 3, q. 16, punct. 3, n. 785A; Martinus Becanus, S.J., De fide, spe et caritate (Lugduni, 1626), "De bello," q. 11.

${ }^{27}$ Vitoria, op. cit., II-II, q. 64, a. 5, n. 7; Thomas Sanchez, S.J., Consilia seu Opuscula Moralia (Lugduni, 1634), t. 2, 1. 6, c. 4, dub. 13, n. 4; Laymann, op. cit., 1. 2, tr. 3, pars 3 , c. 1 , nn. 3-8; c. 3, n. 2; Lessius, op. cit., 1. 2, c. 9, dub. 6, n. 27 ff.; Bonacina, op. cit., 1. 2, 
one foresees will result in the passive scandal of others; ${ }^{28}$ performing an act from which an otherwise illicit pollution or venereal pleasure will arise, when there will be no danger of consenting; ${ }^{29}$ and cooperating materially in another's evil action. ${ }^{30}$

In all these references, although the principle of the double effect is not explicitly expressed, it is applied, as we can gather from the wording used. For the authors either explicitly mention or clearly take for granted that the action performed is good or at least indifferent in itself apart from the evil effect under consideration, and that the intention of performing the action is good. ${ }^{.1}$ Then they explain that the evil effect must not be intentus or per se. Therefore, the evil effect can only be a voluntarium indirectum or an effect per accidens or praeter intentionem. The evil effect must be indirect homicide, scandal, suicide, etc. In these cases, they explain, the evil effect is only permitted. In no case do they allow one to will or intend the evil effect as a means to the good intended, and in some rare cases they even explicitly exclude it. Finally, they all explicitly maintain that these evil effects may be permitted only for "a good reason,"

"De restitutione," disp. 2, q. ult., sect. 1, punct. 5, n. 3; Suarez, op. cit., t. 23 bis, disp. 46, sect. 2, n. 2; Wiggers, op. cit., tr. 2, c. 2, dub. 14, n. 97; Emanuel Sa, S.J., A phorismi Confessariorum (Coloniae, 1609), "Homicidium," n. 18-22; De Coninck, op. cit., t. 2, disp. 13, dub. 13, n. 109; Valentia, op. cit., t. 3, disp. 5, q. 8, punct. 2, n. 1065c.; Martinus Becanus, S.J., De justitia et jure (Parisiis, 1632), "De homicidio," q. 11, n. 6.

${ }^{28}$ Suarez, op. cit., t. 12, tr. 3, disp. 10, sect. 3, 4; Laymann, op. cit., 1. 2, tr. 3, c. 13, n. 8 ff.; Lessius, op. cit., 1. 4, c. 4, dub. 14, n. 113, 114; Valentia, op. cit., t. 3, disp. 3, q. 18, punct. 4, n. 818, D, E; Becanus, De fide, spe et caritate, "de scandalo," q. 6.

${ }^{29}$ Thomas Sanchez, S.J., De sancto matrimonii sacramento (Venetiis, 1712), 1. 9, disp. 45, nn. 4-32; Laymann, op. cit., 1. 3, sect. 4, n. 16; Lessius, op. cit., l. 4, c. 3, dub. 8, n. 60, 65; dub. 14, n. 98-102; Bonacina, 1. 1, pars 2, q. 4, punct. 9, n. 9; Wiggers, op. cit., "De temperantia," c. 3, dub. 12, n. 65, 70; Valentia, op. cit., t. 3, disp. 9, q. 3, punct. 3, n. 1813, C, D; Sa, op. cit., "Luxuria," n. 8; Ferdinand de Castrapalao, S.J., Opus Morale (Lugduni, 1682), 1. 5, tr. 28, disp. 3, punct. 4, par. 2, n. $2 ; 1.7$, tr. 1, disp. 3, punct. 8, par. 2, n. 4, 5; par. 3, n. 5; Azorio, op. cit., t. 3, 1. 3, c. 23, nn. 187, 188; c. 25, n. 193F, n. 194A; Navarrus, (Doctor, Martinus ab Azpilcueta) Manuale Confessariorum (Wirceburgense, 1593), c. 16, n. 7.

${ }^{30}$ Thomas Sanchez, S.J., De praeceptis decalogi (Viterbii, 1738), 1. 1, c. 7, n. 8-18; Laymann, op. cit., 1. 2, tr. 3, c. 13, n. 4, 8; Molina, op. cit., t. 1, tr. 2, disp. 115, n. 4; Bonacina, op. cit., 1. 2, "De restitutione," disp. 1, q. 2, punct. 10, n. 3 ff.; 1. 2, "De legibus," disp. 2, q. 4, punct. 2, n. 17-20; Castrapalao, op. cit., 1. 1, tr. 6, disp. 6, punct. 8-17; Valentia, op. cit., t. 3, disp. 1, q. 10, punct. 5.

at Especially Sanchez, Opuscula Moralia, t. 2, 1. 6, c. 4, dub. 13, n. 4. 
"for a sufficient reason," "for a good cause," or "for a reasonable cause," and in the cases which they judge lawful, they conclude that such a sufficient reason does exist.

These examples, with substantially the same explanations, are given by all the moral theologians down to the present day; so that we can say definitely that the principle of the double effect was accepted generally at least implicitly from the end of the sixteenth century to the present day. However, we must note that the conditions of the principle are contained in most instances very briefly and implicitly in the explanations of the sixteenth and early seventeenth century moralists. At that time the principle was not yet explained as a general moral principle applicable to the whole field of moral theology. The cases mentioned above were treated by the moral theologians as individual cases, and their solutions, as explained, for the most part applied to no other type of case.

The most outstanding link in the further development of the principle of the double effect is that which joins the recognition of the principle as applied to particular sections of moral theology and the recognition of the principle as a general principle applicable to the whole field of moral theology. This most important link is embodied in the treatise, "De peccatis," in the Cursus Theologicus of the Salmanticenses. ${ }^{32}$ It was written originally by Domingo de Sta Teresa (1600-1654) in the year 1647.33 There the author sets out to treat the principle of the double effect, according to his expressed intention, as it applies to the permitting of illicit sexual pleasure. But, in fact, his treatment amounts to a treatment of the principle as applicable to the whole field of moral theology. The authors who come after the Salmanticenses began discussing the principle more and more in their sections of general moral theology, and then in their sections of particular moral problems they referred back to the more general treatment.

The Salmanticenses begin by referring to a general preliminary principle mentioned earlier in their treatise, that sometimes for a sufficient reason illicit sensual pleasure can be permitted without any sin even though that pleasure may arouse the danger of another evil.

2 Salmanticenses, Cursus Theologicus (Parisiis, Bruxellis, 1877), t. 7, tr. 13, disp. 10 dub. 6 , n. $211 \mathrm{ff}$.

as Catholic Encyclopedia in the article on the Salmanticenses. 
Then they explain this principle in detail. ${ }^{34}$ In this explanation of preliminary ideas, they make special notice of the first condition of the principle of the double effect, that there is no question of performing licitly actions that are evil in themselves, but only of those that are good in themselves or at least indifferent, even though these may be vitiated by their effects. They also give an extensive elucidation of fundamental ideas about various kinds of evils and causes, which helps greatly to determine the proportionate reason in the application of the principle.

Continuing their treatise with a lengthy discussion of causes per se and per accidens, the Salmanticenses give a most complete explanation of the three remaining conditions of the principle of the double effect with detailed applications. We quote only some of those passages which indicate that the Salmanticenses held the principle of the double effect as a general principle.

First assertion for causes per se: We must say first that as often as some cause is so determined to an unlawful effect or motion that it either has no other effect, or it results in another effect only by means of the unlawful effect, neither the cause nor the unlawful effect... can be excused from sin either mortal or venial depending on the gravity of the matter....

Second assertion for causes per se: Even though a cause results per se in some evil effect, it is lawful to actuate the cause of that evil effect, if a proportionately serious good effect follows equally immediately from the cause or precedes the evil effect. And although the evil effect may be foreseen, it may not be intended.... Outside the case of necessity the will is obliged to refrain from actuating such a cause....

As often as a great necessity urges one to actuate a cause of such an evil, one may lawfully permit the evil effect. This may be $d$ one whenever, according to the judgment of a prudent man, that cause cannot be omitted without grave inconvenience. The one permitting the evil effect is then considered as one who is morally powerless to prevent it, and by that fact is excused from the obligation....

The prudent man must keep in mind the quality of the matter in question and the differences between the virtues to which the evil permitted is opposed. For, since the virtues do not all oblige with equal force, e.g., justice obliges more strictly than the others, there cannot be an equal obligation to avoid all the various evils even though they be serious. Wherefore

34 Salmanticenses, Cursus Theologicus, t. 7, tr. 13, disp. 10, dub. 6, n. 211-213. 
the same necessity which might be sufficiently serious and urgent to excuse one from the obligation of avoiding the evil of hatred and scandal, or venereal pleasure and pollution, might not be serious enough to excuse from the obligation of avoiding homicide. Again, the necessity must be proportionately greater when the evil permitted is greater in itself, when the cause is closer in nature to the evil, when it is more certain that the evil will result, and when there are fewer ways of preventing the evil after the cause is once actuated. Because of all these differences it is impossible to lay down more particular general rules. Hence, in particular cases one must consult the moral theologians who treat special cases and give solutions deduced from these general principles and applied to all kinds of matter..$^{35}$

After this discussion of causes per se and the general principles, the Salmanticenses also discuss proportionate reasons for permitting causes per accidens. One important class of cases to which they make no reference or application in this treatise is that of lawful material cooperation; yet they give at length the same guides to determine in general a proportionate reason which Thomas Sanchez (1551-1610) had given in his explanation of lawful material cooperation. ${ }^{36}$

The main differences between this discussion by the Salmanticenses and the modern treatment of the principle of the double effect are ones of greater and less complexity in manner of presentation. For, we believe that the modern explanation is less complex in its presentation and more complete in the detailed elaboration of the conditions of the principle, especially in the matter of the criteria for determining a proportionate reason.

\section{THE MODERN PERIOD}

Just how much influence the above endeavor of the Salmanticenses had on the moral theologians who came after them is difficult to say. Strangely enough, the "Salmanticenses Morales" (published first in 1665) give no general treatment of the principle of the double effect, and in their solutions to particular cases they do not refer to the discussion given by their brethren, the "Salmanticenses Scholastici." But from the time of that discussion, the moral theologians more and more recognized the general character of the principle of the

${ }^{25}$ Salmanticenses, Cursus Theologicus, t. 7, tr. 13, disp. 10, dub. 6, n. 214-247.

${ }^{36}$ Sanchez, De praeceptis decalogi, 1. 1, c. 7, n. 12. 
double effect. Busembaum (1600-1668), Mastrius (d. 1673), Gobat (1600-1679), De Cardenas (1613-1684), Gonet (1616-1681), and La Croix (1652-1714) give no general explanation of the principle. However, others with no reference to the "Salmanticenses Scholastici" do give such an explanation, as Reiffenstuel (1641-1703), Roncaglia (1677-1737), Billuart (1685-1757), Elbel (1690-1756), Alphonsus (1696-1787), Bouvier (d. 1854), Gury (1801-1866), Walsh (Tractatus de actibus humanis, published in 1880), and Frins (De actibus humanis, published in 1897). ${ }^{37}$

Compared with the discussion of the principle of the double effect by the "Salmanticenses Scholastici," the general discussions by the moral theologians of the seventeenth and eighteenth centuries is very meager. Reiffenstuel, followed quite literally by Roncaglia, gives a most inadequate treatment in the light of the thorough elucidation of the Salmanticenses. The general explanations of Billuart and Alphonsus, too, although neatly done are also inadequate.

It is only beginning with the various editions of Gury's admirable and repeatedly reedited Compendium Theologiae Moralis in the nineteenth century that the moral theologians universally give an adequate, thorough explanation of the principle of the double effect as a general principle applicable to the whole field of moral theology. In Gury's early editions, the first of which appeared in 1850, the treatment is a complete modern one in brief form. However, since some of the later editions improve on the earlier ones, we shall quote from the fifth German edition published in Ratisbon in 1874.

Gury treats the principle under the general heading of something that is voluntary in its cause. ${ }^{88}$ After defining what he means by something voluntary in its cause, he distinguishes between various kinds of causes, physical and moral, immediate and mediate, proximate and

${ }^{37}$ Anacletus Reiffenstuel, O.M., Theologia Moralis (Venetiis, 1710), tr. 1, dist. 1, q. 2, nn. 12-14; Constantinus Roncaglia, Congr. Matr. Dei, Theologia Moralis Universa (Venetiis, 1760), t. 1, tr. 1, q. 2, c. 1, quaeritur 2, 3; Carolus R. Billuart, O.P., Summa Sancti Thomae (Parisiis, 1839), t. 4, tr. "De actibus humanis," dissert. 1, art. 1, *3; Benjaminus Elbel, O.F.M., Theologia Moralis (Augustae Vindelicorum, 1747), t. 1, conf. 1, n. 23; S. Alphonsus de Ligorio, op. cit., t. 2, 1. 5, tr. "Praeambulus," n. 14; J. B. Bouvier, Institutiones Theologicae (Parisii, 1859), t. 4, tr. "De actibus humanis," c. 1, parag. 3; Gury, op. cit., t. 1, tr. "De actibus humanis," c. 2, nn. 6-10; Walsh, op. cit., nn.. 155-192; Victor Frins, S.J., De actibus humanis (Friburgi Brisgoviae, 1897, 1904), nn. 179-201.

${ }^{28}$ Gury, op. cit., t. 1, tr. "De actibus humanis," c. 2, nn. 6-10. 
remote, and those that are per se and per accidens. Next he discusses the principles for determining the imputability of an evil effect which follows from an intended cause. Among these principles, of course, he places the principle of the double effect which he enunciates and explains as follows:

Principle. It is lawful to actuate a morally good or indifferent cause from which will follow two effects, one good and the other evil, if there is a proportionately serious reason, and the ultimate end of the agent is good, and the evil effect is not the means to the good effect. The reason for this principle is that such an action could be unlawful only from the intention of the evil effect, or from the very actuating of the cause itself, or from the foreseeing of the evil effect. But the action is not unlawful under any one of these headings.

First of all, it is not unlawful on account of the end intended, because the end is good. Secondly, it is not unlawful from the very actuating of the cause itself, because the cause in the supposition is either good or at least indifferent. Thirdly, not on account of the foreseeing of the evil effect, because in the hypothesis the evil effect is not intended but merely permitted; and fourthly, there is a proportionately serious reason for permitting the evil effect. Moreover, not always is there an obligation to prevent the $\sin$ of another who takes occasion for that sin from one's lawful action....

However, all four conditions in this principle must be present at one and the same time, namely the ultimate end of the author must be good, the cause of the effects must be good or at least indifferent, the evil effect must not be the means to the good effect, and there must be a proportionately serious reason for actuating the cause, so that the author of the action would not be obliged by any virtue, e.g., from justice or charity to omit the action.

1. The ultimate end of the author must be good, that is, the author may not intend the evil effect, because otherwise he would intend something evil and consequently commit sin. Hence, too, he may not consent to the evil effect in any way.

2. The cause itself of the effects must be good or at least indifferent, that is, as an act the cause must not be opposed to any law. The reason is evident. For, if the cause is evil in itself, of itself it makes the action imputable as a fault.

3. The evil effect must not be the means to the good effect. The reason is that, if the cause directly produces the evil effect and produces the good effect only by means of the evil effect, then the good is sought by willing the evil. And it is never lawful to do evil, no matter how slight, in order that 
good may come of it.... Therefore, one may never tell a lie even to save some man's life.

4. There must be a proportionately serious reason for actuating the cause, so that the author of the action would not be obliged by any virtue to omit the action. For natural equity obliges us to avoid evil and prevent harm from coming to our neighbor when we can do so without proportionately serious loss to ourselves.

Furthermore, in these cases a more serious reason for acting is necessary, the closer the cause is to the evil effect, the more probable it is that the evil effect will follow from the cause, and the less right the author has to perform the action looked at in itself. ... ${ }^{39}$

Gury then goes on to apply these conditions to particular cases. Later, in the special sections of his Compendium Theologiae Moralis when the principle of the double effect is needed to solve a particular case or to explain his reasoning, he regularly refers back to the general discussion.

With this work of Gury the modern period of the historical development of the principle really begins. After Gury, Walsh and Frins wrote their specialized treatises De actibus humanis, but in the matter of the principle of the double effect they did not add so much as to merit special treatment in this article.

\section{CONCLUSION}

By way of conclusion, we summarize with the following claims. Article seven of question 64 of the Secunda Secundae of St. Thomas' Summa Theologica is the historical beginning of the principle of the double effect as a principle. Although the principle as such was not accepted generally before the sixteenth century, it was accepted generally in its application to particular cases by the moralists of the sixteenth and seventeenth centuries and by all who have succeeded them. In the middle of the seventeenth century the "Salmanticenses Scholastici" provided the most outstanding link in the further development of the principle in their treatise which amounts to a discussion of the principle as applicable to the whole field of moral theology. And the moralist who in a true sense is the first of the moderns in his explanation and application of the principle of the double effect is Gury whose Compendium Theologiae Moralis was first published in 1850.

${ }^{89}$ Gury, fifth German edition, t. 1, tr. "De actibus humanis,"- c. 2, n. 9. 